\title{
Exploitation of Multifarious Abiotic Stresses, Antagonistic Activity and Plant Growth Promoting Attributes of Bacillus amyloliquefaciens AH53 for Sustainable Agriculture Production
}

\author{
Hena Jamali ${ }^{1,3}$, Anjney Sharma ${ }^{1}$, Prity Kushwaha ${ }^{1}$, Prem Lal Kashyap ${ }^{2}$, \\ Roohi $^{3^{*}}$ and Alok Kumar Srivastava ${ }^{1}$ \\ ${ }^{1}$ ICAR-National Bureau of Agriculturally Important Microorganisms, \\ Maunath Bhanjan, India \\ ${ }^{2}$ ICAR-Indian Institute of Wheat and Barley Research (IIWBR), Karnal, India \\ ${ }^{3}$ Department of Bioengineering, Integral University, Lucknow (U.P.), India \\ *Corresponding author
}

\begin{abstract}
A B S T R A C T
Due to climate change, abiotic and biotic stresses like soil salinity, drought, $\mathrm{pH}$, high temperature and plant fungal diseases are major threat for agriculture production and which reduces the growing demand of food of the population. To cope the adverse effect of such stresses, use of wide variety of synthetic chemical fertilizers cause serious hazardous effects on environment, soil, water and human Keylth. Use of microorganisms as a bioinoculants is a new green eco-friendly technology for sustainable agriculture production and can lessen the effect of these stresses. With this respect in the present study a dominant bacterial strain AH53 was isolated from barren agriculture soil of Uttar Pradesh, India for exploiting its unique plant growth promotion properties, tolerance to abiotic stresses, as well as antifungal activities against the fungal pathogens. The results of different level of abiotic stresses tolerance showed that strain AH53 was able to grow up to $14 \% \mathrm{NaCl}, 30 \%$ PEG, between 20 to $50^{\circ} \mathrm{C}$ temperature and 5-9 $\mathrm{pH}$. Further dual culture assay revealed that strain AH53 significantly inhibited mycelial growth of Sclerotium rolfsii and Fusarium avenaceum with the inhibition rate of 86.59 and $85.15 \%$ respectively. The different mode of action for abiotic stresses tolerance and biocontrol activity of the strain AH53 was confirmed by production of multiple plant growth promoting and biocontrol determinants like production of indole acetic acid $(125.24 \mathrm{ug} / \mathrm{ml})$, siderophore, HCN, ACC deaminase, solubilization of phosphate - zinc, production of hydrolytic enzymes and PCR amplification of antimicrobial peptides genes. The 16S rRNA gene sequencing and phylogenetic analysis identified the strain as Bacillus amyloliquefaciens. The results provide evidence that strain AH53 may contribute to its potential activity as mitigation of abiotic stresses and biological control of plants disease to enhancement of sustainable agriculture production under different stressful condition.
\end{abstract}

\section{Introduction}

In Indian economy, agriculture is the main backbone, which either directly or indirectly provides livelihood to approximately $70 \%$ of the country population. Therefore growth in the agricultural sector is essential for the growth and development of the country (Nerker et al., 2013). However, due to global climatic changes, environment typically meets a large number of single and combination of abiotic and biotic stresses, which severely 
affect the growth and production of agricultural crops throughout the world. It has implications for livelihood and survival of human beings. (Radhakrishnan et al., 2017). Among the abiotic stresses, salinity, $\mathrm{pH}$, drought, heavy metals, UV radiation, high and low temperature has been found to be more harmful to crop production $(>50 \%)$ and also these stresses separately impose negative effect at different growth stages of the plants (Grover et al., 2010; Paul and Lade, 2014).

Several earlier studies reported that plants of arid and semi-arid regions often suffers from variety of these abiotic stresses combination, which significantly reduce the quality, yields and productivity of various crops like wheat, chickpea, rice, maize, Mungbean, tomato, grapes and other food staple crops etc (Prasch \& Sonnewald, 2013; Ahmed et al., 2013; Suzuki et al., 2014).

In addition to various abiotic stresses, plants are more susceptible to various bacteria, fungi, nematodes and viruses pathogens attack, face the risk of pathogen infections by weaken the defense mechanisms of plants, which ultimately reduce the crop production (DaamiRemadi et al., 2009; Goudarzi et al., 2011; Gupta et al., 2016; Pandey et al., 2017, Sharma et al., 2018). Plants diseases directly influenced by several abiotic stress factors due to changing the plant physiology and defense mechanisms.

Lamichhane and others (2015) reported the impact of various plant disease combinations on plants. Plant pathologists always consider the effect of variety of environmental stresses on plant diseases. Studies have demonstrated the effect of salinity and drought which makes plants vulnerable to fungal pathogens (Fusarium spp., Rhizoctonia spp., Sclerotium spp., Alterneria spp., Puccinia spp., Pythium spp, and Colletotrichum spp.) (Pandey et al., 2017).
By exerting pressure on agriculture, all these abiotic and biotic stresses variability are likely to aggravate the problem of future food security. Worldwide, research is being carried on large scale to develop strategies to cope the plants with these stresses, through use of chemical fertilizer, development of stress tolerant varieties and resource management practices etc. (Paul and Lade, 2104). The reports reveal that farmers use more than two million tonnes of chemical pesticides each year for getting maximum production. However, such strategies being cost intensive, leads to exhaustion of other essential nutrients and cause negative effects on human and environment health, thereby disturb the entire ecosystem and hampering the agricultural economy. Therefore, in recent years current researches in agriculture are focused on exploration and use of beneficial stress tolerant free-living soil bacteria as a biofertilizer, which is an eco-friendly and cheap approach to ameliorate adverse effects of various abiotic and biotic stresses and development of sustainable agricultural techniques (Mayak et al., 2004; Grover et al., 2010). Under abiotic and biotic stress condition these beneficial free-living soil bacteria successfully colonize in habitats and could contributes in process of nutrient turnover and production of plant growth hormones through various direct and indirect mechanisms. Direct mechanisms includes production of plant hormones like gibberellins, cytokinin and auxin, biological nitrogen fixation, solubilizing of insoluble phosphorus, zinc, and iron, and induction of activated resistance developed by external biological and abiotic stresses, while indirect mechanism is mainly related to inhibition or biocontrol of plant pathogens, through siderophore production by chelating the $\mathrm{Fe}$ compounds in the rhizosphere, production of antimicrobial peptides (AMPs) and extracellular hydrolytic enzymes to degrade the fungal mycelia (Passari et al., 2016; 
Radhakrishnan et al., 2017; Shafi et al., 2017). The occurrence and alleviation of plants from abiotic and biotic stresses, different bacterial genera such as Bacillus, Pseudomonas, Rhizobium, Bradyrhizobium, Pseudomonas, Azotobacter, Azospirillum and Enterobacter has been reported from various extreme environments (Paul and Lade et al., 2014; Sharma et al., 2018). The studies suggest that PGPRs developed complex multilevel regulatory process and produce osmoprotectant to modulate their cytoplasmic osmolarity and support polypeptides folding under denaturing conditions (Sharma et al., 2015, 2018).

Therefore, the need was felt to explore effective plant growth-promoting rhizobacteria (PGPR) that could sustain the stressful environments under abiotic and biotic stress condition. In this regards the aim of the present study was to isolate, identify and characterize potential multi abiotic and biotic stress tolerant plant growth promoting bacteria from barren agricultural soil of Uttar Pradesh, which may be used as an efficient biofertilizer for sustainable increasing the crop production.

\section{Materials and Methods}

\section{Isolation of bacterial strains}

In the present study the soil sample used for isolation of bacterial strains were collected from barren agricultural land of Azamgarh district of Uttar Pradesh, India. After the processing, the soil samples were serially diluted in $90 \mathrm{ml}$ of sterile water in $150 \mathrm{ml}$ Erlenmeyer flasks. $100 \mu \mathrm{l}$ of the serially diluted sample $\left(10^{-3}, 10^{-4}\right.$ and $\left.10^{-5}\right)$ was spread on Nutrient agar (HiMedia, India) plates and incubated at $28^{\circ} \mathrm{C}$ for $48 \mathrm{hrs}$. After the incubation, dominant bacterial colony was purified on same nutrient agar (NA) and maintained in $50 \%$ glycerol at $-80^{\circ} \mathrm{C}$ for further analysis.
Analysis of multiple abiotic stress tolerance ability

The tolerance of all the purified bacterial isolates against different abiotic stresses were screened on nutrient agar (NA) medium under different stresses parameters. The effect of salt $(\mathrm{NaCl})$ stress was studied at 2, 4, 6, 8, 10, 12 and $14 \% \mathrm{NaCl}$ concentration on NA medium at $28^{\circ} \mathrm{C}$.

To study the effect of $\mathrm{pH}$ on bacterial growth was studied by incubating the NA plates at $\mathrm{pH}$ $7,8,9,10,11$ and 12 at $28^{\circ} \mathrm{C}$.

Afterwards, the effect of temperature on bacterial growth was assayed by incubating the plates over different temperature level (15$55^{\circ} \mathrm{C}$ ) at $\mathrm{pH} 7.0$. Subsequently the effect of desiccation on bacterial growth was studied in nutrient broth amended with different concentration of polyethylene glycol (PEG) 0 , 10, 20, 30 and 40\% PEG 6000 at $180 \mathrm{rpm}$, $28^{\circ} \mathrm{C}$ for $48 \mathrm{hrs}$.

\section{Morphological and biochemical characterization}

Morphological and biochemical characterization of the selected bacterial strain was assessed as described in Bergey's Manual of Determinative Bacteriology (Smibert and Krieg, 1994). Bacterial culture was grown on Nutrient Agar medium at $28^{\circ} \mathrm{C}$ for examination of cellular morphology and gram reaction.

Subsequently biochemical characterization of the strain was carried out through standard biochemical tests using $\mathrm{Hi}-25^{\mathrm{TM}}$ Enterobacterial Identification Kit (HiMedia, India). The production of extracellular hydrolytic enzymes viz. amylase, cellulase, lipase, protease and xylanase was studied following the protocol described by Smibert and Krieg (1994). 
Analysis of biocontrol activity against fungal pathogens

The antagonistic activity of the bacterial strain against $F$. avenaceum and $S$. rolsfii were assessed by a dual-culture assay (Sharma $e t$ al., 2018). A freshly grown $8 \mathrm{~mm}$ fungal pathogen mycelia disk was positioned in the centre of mixed nutrient agar and potato dextrose agar (PDA) plate. Freshly grown bacterial culture was streaked on both sides of the fungal disc.

Plates without bacterial culture were used as controls. The experiment was performed in three replication. All the plates were then incubated at $28{ }^{\circ} \mathrm{C}$ for 5-6 days. The growth measurements of the fungal pathogens were recorded and the percent inhibition of fungal mycelium growth was calculated by using the formula:

Percent $(\%)$ inhibition $=(\mathrm{C}-\mathrm{T} / \mathrm{C}) \times 100$

(Where $\mathrm{C}=$ growth in control and $\mathrm{T}=$ growth in treatment).

Analysis of plant growth promoting traits and hydrolytic enzyme production

\section{Indole-acetic acid (IAA) production}

The IAA production was measured by following the standard procedure of Brick et al., (1991). Bacterial culture grown in nutrient broth (NB) for 48 hrs was used for analysis. 4$5 \mathrm{ml}$ bacterial culture was collected from respective cultures tubes and centrifuged at $10,000 \mathrm{~g}$ for $10-15 \mathrm{~min}$. In $2.0 \mathrm{ml}$ of bacterial supernatant, 2-3 drops of orthophosphoric acid plus $4.0 \mathrm{ml}$ of Salkowsky reagent (2\% 0.5 $\mathrm{M} \mathrm{FeCl} 3$ in $35 \% \mathrm{HClO}_{4}$ ) were added and mixed, followed by incubate the reaction mixture at $28 \pm 2^{\circ} \mathrm{C}$ in dark for $1 \mathrm{hr}$. The amount of IAA in the bacterial culture was determined by using a calibration curve of pure IAA $(10-100 \mu \mathrm{g} / \mathrm{ml})$ as a standard.

\section{Phosphate solubilization}

The P-solubilizing activity of the strain was carried out by spot inoculated of the test cultures on NBRIP medium (Mehta and Nautiyal, 2001). The plates were then incubated at $28 \pm 2{ }^{\circ} \mathrm{C}$ for 5-6 days. After the incubation period formation of halo zone around the bacterial colony indicates a positive result for phosphate solubillzation.

\section{ACC deaminase}

ACC deaminase activity of the bacterial strain was determined following the procedure of Penrose and Glick (2003) Bacterial strain was grown in minimal medium (M9) supplemented with ACC (0.03\%) as the sole source of nitrogen, and without ACC as a control. The growth of bacterial strain in ACC supplemented plate was considered as a positive result.

\section{Hydrogen cyanide (HCN) production}

HCN production of the isolates was screened by following the method of Lorck (1948). In Brief, freshly grown bacterial culture was streaked on NA plate supplemented with $4.4 \mathrm{~g}$ glycine/l. Afterwards filter paper (Whatman no. 1) which was pre-soaked in $2 \%$ sodium carbonate in $0.5 \%$ picric acid solution was placed in the top of the plate and then plates were air tight sealed with parafilm. The inoculated and un-inoculated plates were incubated at $28 \pm 2^{\circ} \mathrm{C}$ for $4-5$ days. A change of yellow to orange- red colour indicated positive HCN production.

\section{Siderophore production}

Screening for siderophore production was performed on the Chrome azurol-S agar medium (Sigma, Ltd.) as described by Schwyn and Neilands (1987). The freshly grown bacterial culture spot inoculated in Chrome azurol $\mathrm{S}$ agar plate and incubated at $28 \pm 2^{0} \mathrm{C}$ 
for 48-72 hrs. Development of yellow-orange halo zone around the bacterial colon was considered as positive result for siderophore production.

Molecular identification and phylogenetic analysis

Genomic DNA of the potential bacterial strain was extracted by adopting the standard method of Pospiech and Neumann (1995). The PCR amplification of 16S rRNA gene sequence from the genomic DNA of the bacterial strain was carried out by using the 16S rRNA gene specific universal primers PA (5'-AGA GTT TGA TCC TGG CTC AG-3') and PH (5'-AAG GAG GTG ATC CAG CCG CA-3') (Sharma et al., 2015). The $50 \mu 1$ PCR reaction mixture contained 50-90 ng template DNA with $10 \mathrm{X}$ reaction buffer, $100 \mu \mathrm{M}$ (each) dATP, dCTP, dTTP and dGTP, primers PA and $\mathrm{PH}(100 \mathrm{ng}$ each $)$ and $3 \mathrm{U}$ Taq polymerase. The PCR amplification was carried in a thermal cycler (G-STORM, UK) under the following PCR conditions- initial denaturation at $94{ }^{\circ} \mathrm{C}$ for $4 \mathrm{~min}$, followed by 35 cycles of $94{ }^{\circ} \mathrm{C}$ for $30 \mathrm{sec}$, annealing at 52 ${ }^{\circ} \mathrm{C}$ for $45 \mathrm{sec}$ and extension at $72^{\circ} \mathrm{C}$ for 1.5 min. Final extension period of $8 \mathrm{~min}$ at $72{ }^{\circ} \mathrm{C}$. The agarose gel electrophoresis checked amplified 16S rRNA gene product was purified and sequenced by using Applied Biosystems ABI prism automated DNA sequencer $(3130 x 1)$. Based on 16S rRNA gene sequencing analysis, closely related bacterial sequences present in the NCBI GenBank database were aligned through BLASTn search and identity of the bacterial strain was confirmed. A neighbour-joining phylogenetic tree of the obtained bacterial sequence was constructed (Saitou and Nei 1987) through MEGA 6.0 program by calculating the evolutionary distances with Jukes-Cantor coefficient (Jukes and Cantor 1969). The bootstrap resampling method of Felsenstein (1985) with 1000 replicates was used for evaluation of topology of the phylogenetic tree.

\section{Detection of antimicrobial genes}

The strain AH53 was screened for the presence of AMPs gense (surfactin and iturin) for its approval as potential biocontrol agent. PCR amplification of surfactin ( $\operatorname{srfAA}$ ) gene (F-5'- TCGGGACAGGAAGACATCAT - $3^{\prime}$ ) and R-5'CCACTCAAACGGATAATCCTGA -3'); and iturin (ituC) (F-5'GGCTGCTGCAGATGCTTTAT3') and R(5'- TCGCAGATAATCGCAGTGAG 3') (Solanki et al., 2012) was performed. The PCR amplification was carried out in a thermo cycler (Bio-Rad Laboratories, CA, USA) with the following condition: intitial denaturing at $94^{\circ} \mathrm{C}$ for $4 \mathrm{~min}$; then 35 cycles of denaturation at $92^{\circ} \mathrm{C}$ for $1 \mathrm{~min}$, annealing at $55{ }^{\circ} \mathrm{C}$ for $45 \mathrm{sec}$, and at $72^{\circ} \mathrm{C}$ for $1 \mathrm{~min}$ for extension, followed by a $8 \mathrm{~min}$ extension at $72^{\circ} \mathrm{C}$. The PCR amplified products were checked on 1.5 $\%$ agarose gel with 100 bp ladder (NEB).

\section{Results and Discussion}

\section{Isolation and characterization of bacteria}

To explore the multi stress tolerant microorganism, in the present study a bacterial strain AH53 which was morphologically different and dominant from other colonies on $4 \% \mathrm{NaCl}$ amended nutrient agar plate, was isolated from the barren dry saline agriculture soil of Azamgarh district of Uttar Pradesh, India. The morphological characteristics of the bacterial strain AH53 showed that the colony was medium in size, smooth, round, raised, entire and creamish white in color. Based on the biochemical characteristics, strain AH53 is gram positive, rod shaped, motile and positive for catalase, oxidase, nitrate reduction, $\mathrm{H}_{2} \mathrm{~S}$ production, Voges Proskaur, methyl red, malonate, esculin and negative for ONPG, 
lysine, ornithine, phenylanine, indol and urea hydrolysis (Table 1). The results of carbon source utilization showed that strain AH53 was metabolically active and easily utilize xylose, cellobiose, saccharose, raffinose, trehalose, glucose. Based on these characteristics, strain AH53 tentatively recogniszed as genus Bacillus (Table 1).

The ribosomal gene (16S rDNA) sequencing is reliable for identification of prokaryotes at molecular level (Sharma et al., 2015). Molecular identification of strain AH53 was analyzed through $16 \mathrm{~S}$ rRNA gene sequencing analysis. Sequencing result was searched against NCBI GenBank database, using BLASTn. A 1428 bp gene sequence of strain AH53 displayed 99\% similarity with Bacillus amyloliquefaciens. The neighbor-joining phylogenetic tree further confirmed that this isolate is phylogenetically related to the other B. amyloliquefaciens strains. Sequence was submitted in NCBI database (GenBank) with accession number MH810308 (Table 1 and Fig. 1).

\section{Analysis of multiple abiotic stress tolerance ability}

Screening the microorganisms for abiotic stresses tolerance should be an important attribute in selection of indigenous strains for developing potential microbial inoculants. Bacterial strain AH53 was analyzed for their stress tolerance attributes against salinity, $\mathrm{pH}$ and temperature. Strain AH53 showed luxuriant growth on NA plates supplemented with different range of $\mathrm{NaCl}(2,4,6,8.10,12$ and $14 \%(\mathrm{w} / \mathrm{v})), \mathrm{pH}(5.0$ to 9.0$)$ and temperature $\left(20-50^{\circ} \mathrm{C}\right)$. Strains also differed in their ability to grow under drought stress. Strains AH53 tolerated the desiccation regime of 0-30\% PEG 6000 in nutrient broth (Table 2). A decrease in growth pattern was observed with increase in stress concentration.
Analysis of biocontrol activity against fungal pathogens

Utilization of biocontrol agents to inhibit growth of fungal pathogens is an effectivefriendly approach and can be substitute of chemical fungicides to control the negative harmful effects of various plant pathogens and development of sustainable agricultural techniques (Sharma et al., 2018). In the present study strain AH53 was subjected for in-vitro antagonistic activity (dual-culture assay) against the fungal pathogens $S$. rolfsii and $F$. avenaceum. $S$. rolfsii is a versatile soilborne fungus plant pathogen which cause southern blight disease in broad host range of more than 600 species in tropical and subtropical regions (Zhong et al., 2016).

The diseases caused by this pathogenic fungus are more severe because the brownish sclerotia of the $S$. rolfsii can survive in soil for long time, which worked as initial inoculum source for disease development. Similarly, $F$. avenaceum causing foot rot, seedling blight, dry land root rot of cereals, blights of plant species, is also a broad host range plant pathogen responsible for disease on $>80$ genera of plants through production of mycotoxins (Palazzinia et al., 2013). The results of dual culture assay on NA-PDA agar plate showed that strain AH53 showed highest inhibitory and antagonistic effect against the $S$. rolfsii with the maximum percent mycelial inhibition $86.59 \pm 0.24 \%$ followed by against the $F$. avenaceum with $85.15 \pm 0.68 \%$ mycelial inhibition (Table 2 and Fig.2). The inhibition of fungal pathogen's mycelia growth may be due to the ability of the strain for siderophore, $\mathrm{HCN}$ and antimicrobial metabolite production or hydrolytic enzyme like protease production. Due to siderophores production the ferric iron is sequestrated in the form which cannot be used by the fungal or other plants pathogens, and finally the number or activity of pathogens reduced. 
Table.1 Morphological, biochemical and molecular characterization of the strain AH53

\begin{tabular}{|c|c|c|c|c|c|}
\hline Characteristics & $\begin{array}{c}\text { Results of } \\
\text { AH53 }\end{array}$ & Characteristics & Results of AH53 & Characteristics & Results of AH53 \\
\hline \multicolumn{2}{|c|}{ Morphological \&Biochemical } & Malonate & + & PGP attributes & \\
\hline Colony color & $\begin{array}{l}\text { Creamish- } \\
\text { white }\end{array}$ & Esculin & + & & \\
\hline Cell Shape & Rod & & & IAA production & $\begin{array}{c}125.24 \pm 1.14 \\
\mathrm{ug} / \mathrm{ml}\end{array}$ \\
\hline Motility & + & C-source utilization & & P -solubilization & ++ \\
\hline Gram Reaction & + & Arabinose & - & ACC deaminase & ++ \\
\hline ONPG & - & Xylose & + & Siderophore & ++ \\
\hline Lysine & - & Adonitol & - & $\begin{array}{l}\text { Zinc- } \\
\text { solubilization }\end{array}$ & ++ \\
\hline Ornithine & - & Rhamnose & - & $\mathrm{HCN}$ & ++ \\
\hline Catalase & + & Cellobiose & + & & \\
\hline Oxidase & + & Melibiose & - & & \\
\hline Urea hydrolysis & - & Saccharose & + & Hydrolytic enzy & \\
\hline Phenylanine & - & Raffinose & + & & \\
\hline Nitrate & + & Trehalose & + & Amylase & ++ \\
\hline H2S & + & Glucose & + & Cellulase & +++ \\
\hline Citrate & - & Lactose & - & Protease & +++ \\
\hline Voges Proskaur & + & & & Xylanase & ++ \\
\hline Methyl red & + & $\begin{array}{l}\text { Molecular } \\
\text { Characteization }\end{array}$ & B. amyloliquefaciens & Lipase & + \\
\hline Indole & - & $\begin{array}{l}\text { NCBI GenBank Acc. } \\
\text { No. }\end{array}$ & MH810308 & Gelatinase & - \\
\hline
\end{tabular}

(+) Positive for test, (-) negative for test, $(++)$ production in medium level, $(+++)$ production in high level 
Table.2 Different abiotic and biotic (biocontrol activity) stress tolerance of the strain AH53

\begin{tabular}{|c|c|c|c|}
\hline Type of stress & Observations & Type of stress & Observations \\
\hline $\mathrm{NaCl}$ tolerance $(\%)$ & & Temp. tolerance $\left({ }^{\circ} \mathrm{C}\right)$ & \\
\hline 2 & +++ & 20 & ++ \\
\hline 4 & +++ & 30 & +++ \\
\hline 6 & +++ & 40 & +++ \\
\hline 8 & +++ & 50 & ++ \\
\hline 10 & ++ & 55 & + \\
\hline 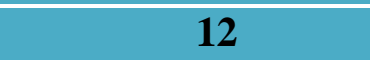 & ++ & Desiccation (PEG) tolerance (\%) & \\
\hline 14 & ++ & 10 & +++ \\
\hline pH tolerance & & 20 & +++ \\
\hline 4 & - & 30 & +++ \\
\hline 5 & ++ & 40 & - \\
\hline 6 & +++ & & \\
\hline 7 & +++ & Biocontrol activity (\% inhibition) & \\
\hline 8 & +++ & Sclerotium rolfsii & $86.59 \pm 0.24$ \\
\hline 9 & ++ & Fusarium avenaceum & $85.15 \pm 0.68$ \\
\hline
\end{tabular}

(+) Positive for growth, (-) negative for growth, $(++)$ healthy growth, $(+++)$ luxurious growth 
Fig.1 Phylogenetic tree of partial 16S rDNA sequences of Bacillus amyloliquefaciens strain AH53 with those of maximum similar entries from database. The tree is created by neighborjoining method with 1000 bootstrap re-samplings. Scale bar represents the number of changes per base position

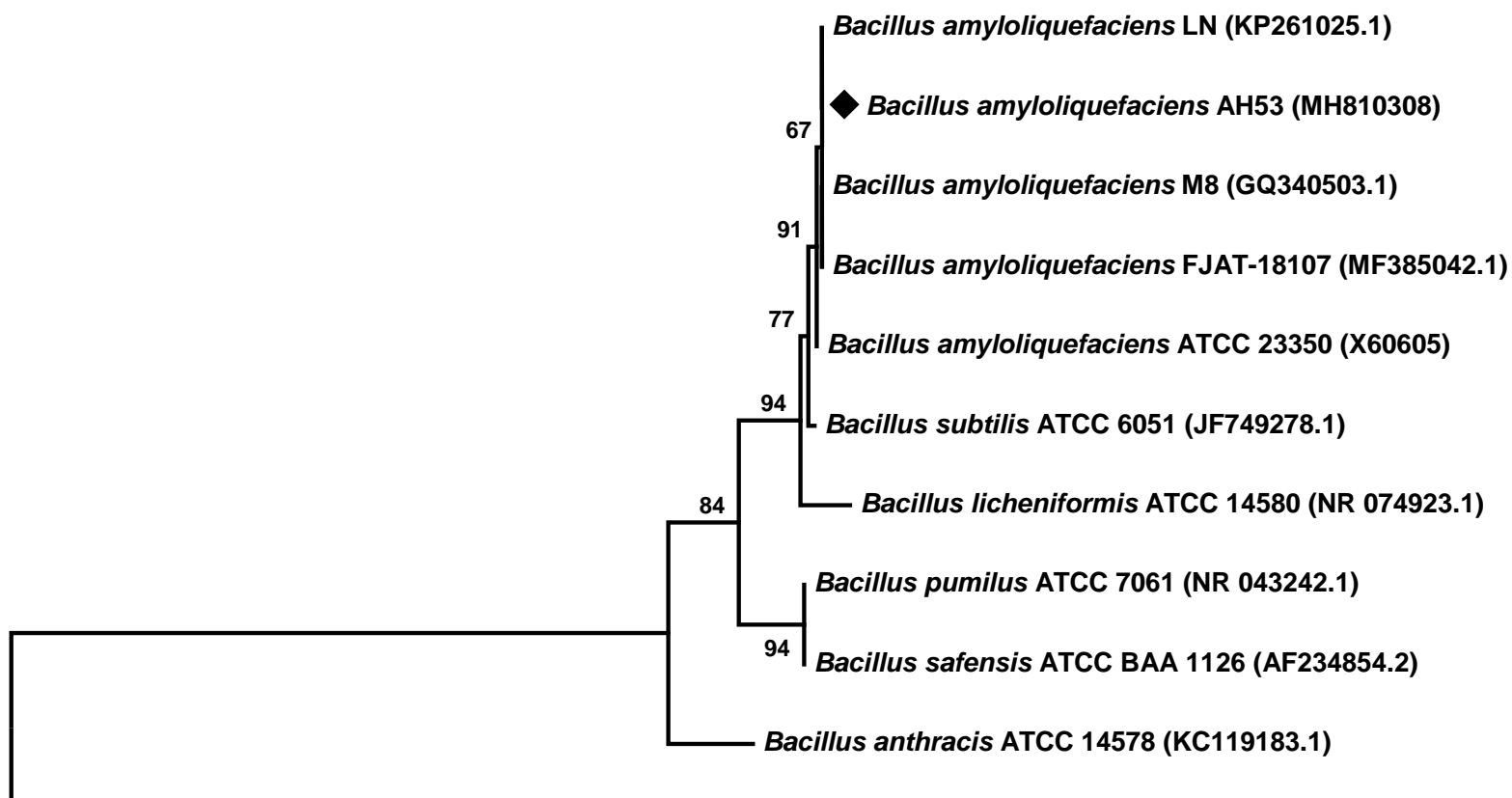

Pseudomonas aeruginosa ATCC 10145 (NR 114471.1)

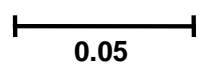

Fig.2 Antagonism activity of Bacillus amyloliquefaciens strain AH53 against fungal phytopathogens; (A) Control: Fusarium avenaceum (B) Antagonism activity of strain AH53 against Fusarium avenaceum; (C) Control: Sclerotium rolfsii (D) Antagonism activity of strain AH53 against Sclerotium rolfsii

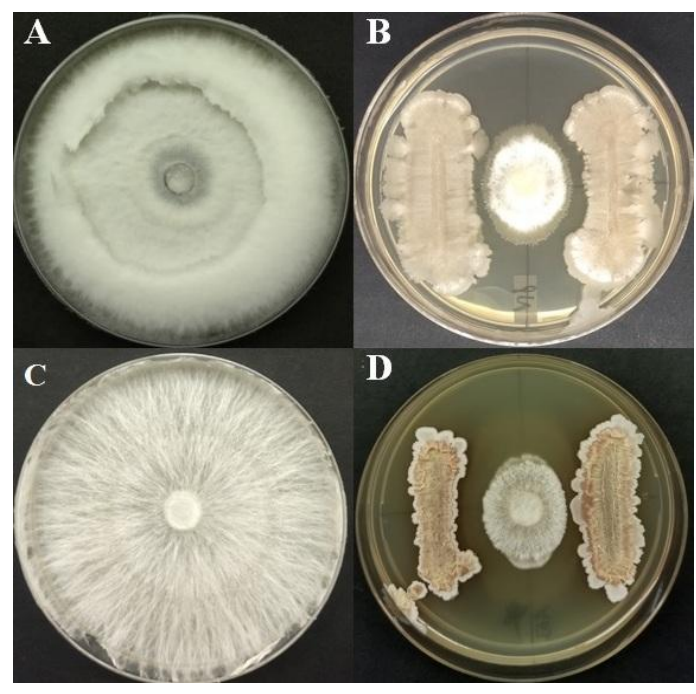


Fig.3 PCR amplification of AMPs genes in Bacillus amyloliquefaciens strain AH53. [A] M: Molecular marker 100 bp size and surfactin: $\operatorname{srfAA}(\sim 201 \mathrm{bp})$ gene amplification; [B] M: Molecular marker 100 bp size and iturin: ituC ( 423b) gene amplification

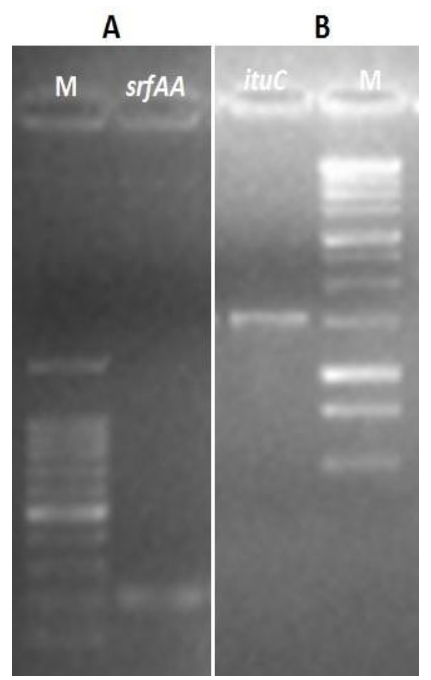

Several other workers also reported that metabolites and hydrolytic enzymes produced by Bacillus genera have antifungal activity against phytopathogens (Singh et al., 2014; Shafi et al., 2017; Sharma et al., 2018). These results suggest that strain AH53 obtained in the present study may be used as efficient biocontrol agent against $F$. avenaceum and $S$. rolfsii.

\section{Detection of antimicrobial genes}

The suppression of fungal disease by the microorganism is governed by a huge number of factors in ecosystems. The influence of these factors varies with the nature of pathogen targeted, type of biocontrol agent involved and also cropping system involved (Singh et al., 2014). There are different modes of action for biocontrol of pathogens by the bacteria, in which production of antimicrobial peptides play a major role (Singh et al., 2014). Several earlier workers reported that Bacillus spp. secrete a wide range of antimicrobial peptides (AMPs) such as bacilysin, bacillomycin, fengycins, iturins, surfactins, and subtilin (Singh et al., 2014; Zouari et al., 2016; Sharma et al., 2018). In present study, PCR amplification of antimicrobial peptides (AMPs) gene confirmed that selected $B$. amyloliquefaciens strain AH53 was positive for presence of surfactin $(\operatorname{srfAA})$ and iturin $(i t u C)$ genes with amplification of single band of $~ 201$ and 423 bp respectively (Fig. 3). These AMPs break the cell membranes and creates ionconducting pore channels and leads to cellular leakage, abnormalities in hyphal such as swelling, malformations and disintegration of hyphal cells (Kumar et al., 2017; Sharma et al., 2018). Thus, presence of these AMPs genes in the bacterial strain AH53 confirmed its potential as biocontrol agent against phytopathogens.

\section{Analysis of plant growth promoting traits and hydrolytic enzyme production}

Several studies established that bacterial strains with multiple plant growth promotion attributes are very helpful in growth and development of plants under various stressed conditions (Sharma et al., 2015; Radhakrishnan et al., 2017). There are various mechanisms (production of hormones auxin (IAA), ACC deaminase, cytokinin, 
gibberellins, solubilisation of phosphate, zinc, potassium and production of production of siderophore, HCN, ammonia, antibiotics and hydrolytic enzymes) involved in the abiotic stresses tolerance and inhibition of phytopathogens (Shafi et al., 2017). Strain AH53 exhibited multiple plant growth promoting attributes (Table 1 and Fig. 4). Strain AH53 was able to produce IAA $(125.24 \pm 1.14 \mathrm{ug} / \mathrm{ml})$.

The test strain was able to solubilise phosphate by showing clear zones around the colony on NBRI agar medium. In addition, strain AH53 was found positive for siderophore, and $\mathrm{HCN}$ production.

Further strain AH53 was screened for their ability to produce extracellular hydrolytic enzymes. Results showed that strain AH53 was able to produce amylase, cellulase, protease, lipase and xylanase after the staining on agar plate (Table 1 and Fig.4).

This study emphasized for evaluating the plant growth promoting potential of bacterial strain Bacillus amyloliquefaciens AH53. Results showed that strain AH53 has ability to tolerate multiple abiotic stresses and possess biocontrol activity and plant growth promoting attributes. Bacillus amyloliquefaciens AH53 may be used for sustainable agriculture production under different stress conditions.

\section{Acknowledgements}

The authors gratefully thank the Director, ICAR-NBAIM, Maunath Bhanjan (U.P.) for providing necessary support for conducting the research work and_acknowledge the Office of Dean, Research and Development, Integral University, Lucknow (U.P.), ia for critically reviewing the manuscript and providing the manuscript number (IU/R\&D/2018-MCN000456).

\section{References}

Ahmed, I.M., Dai, H., Zheng, W., Cao, F., Zhang, G., Sun, D and Wu, F. 2013. Genotypic differences in physiological characteristics in the tolerance to drought and salinity combined stress between Tibetan wild and cultivated barley. Plant Physiology and Biochemistry. 63: 49-60.

Bric, J.M., Bostock, R.M and Silverstone, S.E. 1991. Rapid in situ assay for indoleacetic acid production by bacteria immobilized on a nitrocellulose membrane. Appl Environ Microbiol. 57: 535-538.

Daami-Remadi, M., Souissi, A., Oun, H. B., Mansour, M., and Nasraoui, B. 2009. Salinity effects on fusarium wilt severity and tomato growth. Dyn. Soil Dyn. Plant 3: 61-69.

Felsenstein, J., 1985. Confidence limits on phylogenies: an approach using the bootstrap. Evolution 39: 783-791.

Goudarzi, S., Banihashemi, Z., and Maftoun, M. 2011. Effect of salt and water stress on root infection by Macrophomina phaseolina and ion composition in shoot in sorghum. Iran J. Plant Pathol. 47: 69-83.

Grover, M., Ali, S.K., Sandhya, V., Rasul, A and Venkateswarlu, B. 2010. Role of microorganisms in adaptation of agriculture crops to abiotic stresses. World Journal of Microbiology and Biotechnology.DOI 10.1007/s11274010-0572-7.

Gupta, A., Dixit, S. K., and Senthil-Kumar, M. 2016. Drought stress predominantly endures Arabidopsis thaliana to Pseudomonas syringae infection. Front. Plant Sci. 7:808. doi: 10.3389/fpls.2016.00808.

Jie, Zhong., Dan, Chen., Hong, J., Zhu, Bi.D., Gao and Qian, Zhou. 2016. Hypovirulence of Sclerotium rolfsii 
caused by associated RNA mycovirus. Frontiers in Microbiology, doi: 10.3389/fmicb.2016.01798.

Jukes, T.H and Cantor, C.R. 1969. Evolution of protein molecules. In: Munro HN (ed) Mammalian protein metabolism, vol 3. Academic Press, New York.

Lorck, H. 1948. Production of hydrocyanic acid by bacteria. Physiol Plant. 1:142146.

Mayak, S., Tirosh, T and Glick, B.R. 2004. Plant growth-promoting bacteria that confer resistance to water stress in tomatoes and peppers. Plant Sci. 166: 525-530.

Mehta, S and Nautiyal, C.S. 2001. An efficient method for qualitative screening phosphate-solubilizing bacteria. Curr. Microbiol. 43(1): 51-56. doi:10.1007/s002840010259. PMID: 11375664.

Nerker, K. R., Kale and Bhadale, R. 2013.

The sustainable growth and development of Indian agriculture. Asia Pacific Journal of Marketing and Management Review. 2(6): 117-119.

Palazzinia, J.M., Groenenboom-de Haasb, B.H., Torresa, A.M., hlb, J.K and Chulzea, S.N. 2013. Biocontrol and population dynamics of Fusarium spp. on wheat stubble in Argentina. Plant Pathology. 62: 859-866.

Pandey, P., Irulappan, V., Bagavathiannan, M.V and Kumar M.S. 2017. Impact of combined abiotic and biotic stresses on plant growth and avenues for crop improvement by Exploiting Physiomorphological Traits. Frontiers in Microbiology. doi: 10.3389/fpls.2017.00537.

Passari, P., Zothanpuia., Mishra, V.K., Leo, V.V., Gupta, V.K., Kumar B and Singh, B.P. 2016. Detection of biosynthetic gene and phytohormone production by endophytic actinobacteria associated with Solanum lycopersicum and their plant-growth-promoting effect. Res Microbiol. 167(8):692-705. doi: 10.1016/j.resmic.2016.07.001

Paul, D and Lade, H., 2014. Plant-growthpromoting rhizobacteria to improve crop growth in saline soils: a review. Agron. Sustain. Dev. 34: 737-752.

Penrose, D.M and Glick, B.R. 2003. Methods for isolating and characterizing ACC deaminase-containing plant growthpromoting rhizobacteria. Physiol. Plant 118 (1): $10-15$.

Pospiech, A and Neumann, B., 1995. A versatile quick-prep of genomic DNA from gram positive bacteria. Trends Genet. 11 (6): 217-218.

Prasch, C.M and Sonnewald, U. 2013. Simultaneous application of heat, drought, and virus to Arabidopsis plants reveals significant shifts in signaling networks. Plant Physiology 162: 18491866.

Radhakrishnan, R., Hashem, A and Abdullah, E.F. 2017. Bacillus: A Biological Tool for Crop Improvement through BioMolecular Changes in Adverse Environments. Front. Physiol. 8:667. doi: 10.3389/fphys.2017.00667.

Saitou, N and Nei, M., 1987. The neighbourjoining method: a new method for reconstructing phylogenetic trees. Mol. Biol. Evol. 4(4): 406-425.

Schwyn, B and Neilands, J. 1987. Universal chemical assay for the detection and determination of siderophores. Anal Biochem.160:47-56.

Shafi, J., Tian, H and Mingshan, J. 2017. Bacillus species as versatile weapons for plant pathogens: a review. Biotechnology \& Biotechnological Equipment, 31(3): 446-459. DOI: 10.1080/13102818.2017.1286950.

Sharma, A., Kashyap, P.L., Srivastava, A.K., Bansal, Y.K and Kaushik, R. 2018. Isolation and characterization of 
halotolerant bacilli from chickpea (Cicer arietinum L.) rhizosphere for plant growth promotion and biocontrol traits. Eur J Plant Pathol. doi.org/10.1007/s10658-018-1592-7.

Sharma, A., Singh, P., Kumar, S and Kashyap, P.L, et al., 2015. Deciphering diversity of salt-tolerant bacilli from saline soils of eastern indo-gangetic plains of India. Geomicrobiology. 32:170-180.

Singh, R.K., Kumar, D.P., Singh, P and Solanki, M.K, et al., 2014. Multifarious plant growth promoting characteristics of chickpea rhizosphere associated Bacilli help to suppress soil-borne pathogens. Plant Growth Regulation. 73:91-101.

Smibert, R and Krieg, N. 1994. Phenotypic characterization. Methods for general and molecular bacteriology. 607-654.

Solanki, M.K., Robert, A.S., Singh, R.K., Kumar, S and Pandey, A.K, et al., 2012. Characterization of mycolytic enzymes of Bacillus strains and their bioprotection role against Rhizoctonia solani in tomato. Curr Microbiol. 65:330-336.

Suzuki, N., Rivero, R.M., Shulaev, V., Blumwald, E and Mittler, R. 2014. Abiotic and biotic stress combinations. New Phytologist. 203: 32-43. doi: 10.1111/nph.12797.

Vinodkumar, S., Nakkeeran, S., Renukadevi, P and Malathi, V.G. 2017. Biocontrol potentials of antimicrobial peptide producing Bacillus species: Multifaceted antagonists for the management of stem rot of carnation caused by Sclerotinia sclerotiorum. Frontier in Microbiology. doi: 10.3389/fmicb.2017.00446.

Vyas, P., Rahi, P., Chauhan, A and Gulati, A. 2007. Phosphate solubilizing potential and stress tolerance of Eupenicillium parvum from tea soil. Mycol Res. 111:931-938.

\section{How to cite this article:}

Hena Jamali, Anjney Sharma, Prity Kushwaha, Prem Lal Kashyap, Roohi and Alok Kumar Srivastava. 2018. Exploitation of Multifarious Abiotic Stresses, Antagonistic Activity and Plant Growth Promoting Attributes of Bacillus amyloliquefaciens AH53 for Sustainable Agriculture Production. Int.J.Curr.Microbiol.App.Sci. 7(10): 751-763. doi: https://doi.org/10.20546/ijcmas.2018.710.083 